\title{
Psychological Wellbeing in Cervical and Breast Cancer Survivors: Differences in Each Stage of Survivorship
}

\author{
Ni Putu Wulan Purnama Sari \\ Faculty of Nursing, Widya Mandala Catholic University Surabaya \\ wulanpurnama@ukwms.ac.id
}

\begin{abstract}
Being diagnosed with cancer in some females results in impaired psychological wellbeing (PWB). This study aimed to compare and analyze the PWB between cervical and breast cancer survivors (CCS and BCS) especially in each stage of survivorship. This cross-sectional study involved 47 CCS and 58 BCS $(n=105)$ from three districts in Surabaya, Indonesia. QOL-CS was used for collecting data. Independent sample T test, one way ANOVA test, and linear regression test were used in data analysis $(\alpha<0.05)$. Results showed that most respondents had sufficient PWB. PWB between cases and survivorship stages was not significantly different $(p=0.067$ overall, $p=0.425$ in $C C S$, and $p=0.135$ in $B C S)$. In $C C S$, appearances and self-concept were significantly changing over time $(p=0.032$ and $p=0.007$ respectively); meanwhile in BCS, life acceptance, happiness, memory/concentration, and usefulness were continuously changed $(p=0.044, p=0.019, p=0.020$, and $p=0.018$ respectively). Appearances were the best predictor of PWB in both cases $(p=0.000)$, but it gave more influences in BCS than CCS $(52.6 \%$ vs. $29.7 \%)$.
\end{abstract}

Keywords: breast cancer, cancer, cancer survivorship, cervical cancer, psychological wellbeing

Received 13 May 2019/Accepted 28 February 2020 @JEHCP All rights reserved

\section{Introduction}

Cancer is a disease caused by the damaged of certain genes that control the process of cell regeneration in our body resulted in abnormal cell growth (Kaplan, 2008). A massive longitudinal study worldwide was conducted to analyze the epidemic of cervical and breast cancer incidence and mortality by results of global breast and cervical cancer incidence rate increased $3.1 \%$ and $0.6 \%$ annually since 1980 until 2010 respectively, while the mortality in 2010 was 425,000 and 200,000 for breast and cervical cancer respectively in which most death occurred in the age group of 15-49 years old (Forounzafar, et al., 20II).

Nationally, Indonesian cancer incidence was $0.1 \%$ and unfortunately $50 \%$ of cancer patients who firstly seeking for therapy was in an advanced stage (Tejawinata, 20I2). In 20I3, national cancer prevalence was $1.4 \%$ in which $0.8 \%$ and $0.5 \%$ o for breast and cervical cancer respectively; the state 
of Yogyakarta had the highest prevalence of breast and cervical cancer at the same time, while estimation results showed that the state of Central and East Java had the highest prevalence of both cancers (Ministry of Health, 20I5).In 20I7, breast cancer still holds the ${ }^{\text {st }}$ position as the highest new cases and deaths in Indonesian cancer statistics (Arafah \& Notobroto, 2017); detail explanation about Indonesia's cancer profiling in 2017 was not available online yet. In the period of four years we can see that more women suffered from breast cancer than cervical cancer. In Surabaya community of 2018, mostly breast cancer occurred in middle and late adulthood, while mostly cervical cancer occurred in middle-late adulthood and elderly; both cancers tend to occurred earlier towards middle adulthood if compared to the national cancer situation in 2013 (Sari, 20I8).

The life expectancy of people living with cancer increases steadily due to advances in diagnosis and therapy, but unfortunately these advancements also resulted in long term burden needed long-term supportive and palliative care. The stage of survivorship in cancer categorizes into three, namely: acute ( $<\mid$ year), short term ( $\mathrm{I}-5$ years), and long term survivorship ( $>5$ years) [Campo, et al., 2016]. In Surabaya community, most survivors of breast and cervical cancers live with the disease for less than five years, but cervical cancer survivors (CCS) tend to live longer if compared to breast cancer survivors (BCS) because more women with advanced stage cervical cancer were found to be long-term survivors who live with the disease for more than five years (Sari, 2018).

Wellbeing, or "mental health," is a construct which developed by the summary of physical capacity, emotional capacity, spiritual capacity, cognitive capacity (La Placa, McNaught, \& Knight, 20I3). Psychological wellbeing (PWB), especially in adult, is a construct which developed by six dimensions, namely: self-acceptance, positive relations with others, autonomy, environmental mastery, purpose in life, and personal growth (Demiray \& Bluck, 2014). Specifically, PWB in cancer survivors is a construct which developed by the summary of life satisfaction, life quality, happiness, take control of life, life satisfaction, memory/concentration, usefulness, appearances, and self concept (Ferrel, Hassey-Dow, \& Grant, 1995). This study context used the construct of PWB in cancer survivors as theoretical framework. 
Wellbeing, especially PWB in this case, is an intangible concept which difficult to define and even harder to measure (Thomas, 2009). Dodge, Daly, Huyton, \& Sanders (2012) tried to propose a new definition of wellbeing which centre on a state of equilibrium or balance that can be affected by life events or challenges. Subjective wellbeing consists of three interrelated components: life satisfaction, pleasant affect $(+)$ and unpleasant affect (-) [Diener \& Suh, 1997]. Bradburn (1969), the classic researcher who referred PWB to happiness, concluded that an individual will be high in PWB in the degree to which he has an excess of positive over negative affect; and will be low in PWB in the degree to which negative affect predominates over positive. Research in PWB has been growing in recent decades. In the context of chronic illnesses other than cancer, research on PWB has been conducted in diabetic people (Tristiana, Kusnanto, Widyawati, Yusuf, \& Fitryasari, 20I6), hypertensive adults (Trudel-Fitzgerald, Boehm, Kivimaki, \& Kubzansky, 20I4), chronic kidney failure (Seraji, Shojaeizadeh, \& Rakhshani, 2018), cardiovascular disease (Kubzansky, et al., 2018), osteoarthritis (Weathers \& Creedon, 20II), and many more. The abovementioned study results agreed that positive PWB had positive impact on the physical and psychological parameters measured.

The construct of quality of life (QOL) in cancer survivors is developed by the summary of physical, psychological, social, and spiritual wellbeing; therefore PWB is in importance to be studied further in order to predict the QOL, especially in CCS and BCS because these two cases being very prevalent in women worldwide (Forounzafar, et al., 20II). So far, study about PWB was done separately in breast cancer (Abu-Helalah, Al-Hanaqta, Alshraideh, Abdulbaqi, \& Hijazeen, 20I4) and gynaecologic cancer (Vitale, La Rosa, Rapisarda, \& Lagana, 2017); there is no comparative study between cases found yet. In addition, both studies were not associating PWB with survivorship stages in both cases, and there is no comparative study between stages of survivorship in each case yet. This study aimed to: I) compare and analyze the PWB between CCS and BCS generally, and between stages of survivorship in both cases specifically, and 2) determine the best predictor of PWB in CCS and BCS. 


\section{Method}

Design

This study utilized cross-sectional design in which all parameters were measured once in a time without any follow-up. Therefore this study presented the point prevalence, but unable to show the fluctuation of variables' values over time.

\section{Sample}

There were 47 CCS and 58 BCS in the district of Rangkah, Gading, and Pacarkeling, Surabaya, Indonesia, recruited to be study respondents, which consisted of 27, 45, and 33 acute, short-term, and long-term survivors respectively. Inclusion criteria werebeing an adult (> 18 years old) with cancer diagnosis that has been confirmed by the authorized Public Health Center (PHC) in the abovementioned districts, and regularly home-visited by a palliative volunteer under the supervision of Rangkah PHC. Exclusion criteria were rejection on filling out the consent form, hospitalization, mental illness, and impaired consciousness or disorientation. Total sampling was applied and sample size of 105 was obtained.

\section{Instrument}

Questionnaire of Quality of Life - Cancer Survivor (QOL-CS) which developed by Ferrel, HasseyDow, \& Grant (1995) was used in data collection process. This instrument consisted of four parts in which part II was specifically assessed the PWB in cancer survivors. QOL-CS part II consisted of 10 items with interval data scale. Likert scale of 0 to 10 was used to differentiate individual response. Three categories were used to differentiate response levels in each item: low (0-3), sufficient (4-6), and high (7-10). These categories were made in order to ease the data interpretation and presentation only.

\section{Data collection and analysis}

Data were collected since February until March, 2018, in the district area of Rangkah, Gading, and Pacar Keling, Surabaya, Indonesia, by door to door method. Three enumerators were recruited to be research assistants, especially for collecting data. Independent sample T test, one way ANOVA, and simple linear regression test were used in data analysis $(\alpha<0.05)$. Interval data scale was used in statistical analysis by utilizing the raw score of PWB. 


\section{Ethical consideration}

Ethical clearance was issued by Faculty of Nursing, Universitas Airlangga, Surabaya, Indonesia, with certificate number of $68 \mathrm{I}-\mathrm{KEPK}$.

\section{Result}

In this study context, more cases of breast cancer were found. This result further confirmed that breast cancer was still being the top leading cases of female cancer in Indonesia since 20I4. Breast cancer was mostly occurred in the age group of 4I-60 years old with tendency to younger age, while opposite condition was found in cervical cancer. Most respondents were married but most CCS had no child, while most BCS live with their spouse and children. More single women were found to have breast cancer in this study.BCS had better educational background, occupational status, and GDP than CCS, but overall most respondents had low socioeconomic status. Table I below shows the demography characteristic of study respondents in details.

Table I: Demography Characteristic

\begin{tabular}{llcccc}
\hline \multicolumn{1}{c}{ Characteristic } & \multicolumn{2}{c}{ Cervical Cancer $(\mathrm{N}=47)$} & \multicolumn{2}{c}{ Breast Cancer $(\mathrm{N}=58)$} \\
\cline { 2 - 5 } & Frequency & $\%$ & Frequency & $\%$ \\
\hline I. Age (years old) & 0 & 0 & 1 & 1.72 \\
a. $<21$ & 0 & 0 & 5 & 8.62 \\
b. 2I-30 & 5 & 10.64 & 10 & 17.24 \\
c. 3I-40 & 11 & 23.40 & 15 & 25.86 \\
d. 4I-50 & 17 & 36.17 & 15 & 25.86 \\
e. 5I-60 & 13 & 27.66 & 8 & 13.79 \\
f. 6I-70 & 1 & 2.13 & 4 & 6.90 \\
g. > 70 & & & & 1.72 \\
2. Religion & 0 & 0 & 1 & 18.97 \\
a. Catholic & 7 & 14.89 & 11 & 79.31 \\
b. Christian & 40 & 85.11 & 46 & \\
c. Islam & & & & 98.28 \\
3. Ethnic & 40 & 85.11 & 57 & 0 \\
a. Javanese & 6 & 12.76 & 0 & 1.72 \\
b. Maduranese & 1 & 2.13 & 1 & 18.97 \\
c. Chinese & & & & 8.62 \\
4. Educational background & 15 & 31.91 & 11 & 44.83 \\
a. Primary school & 14 & 29.79 & 5 & 1.72 \\
b. Secondary school & 13 & 27.66 & 26 & 13.79 \\
c. High school & 2 & 4.25 & 15 & 1 \\
d. Diploma / Bachelor degree & 3 & 6.38 & & \\
e. Uneducated & & & & \\
5. Marital status & 3 & 6.38 & 8 & \\
a. Single & & & &
\end{tabular}




$\begin{array}{lcccc}\text { b. Married } & 39 & 82.98 & 36 & 62.07 \\ \text { c. Widow } & 4 & 8.51 & 14 & 24.14 \\ \text { d. Divorce } & 1 & 2.13 & 0 & 0\end{array}$

6. Living at home with
a. Spouse
b. Children
c. Alone
d. Parents
e. Sibling

82.98

36.17

30

51.72

6.38

60.34

3.45

18.97

3.45

7. Occupational status
a. Full-timer
b. Part-timer
c. Retired
d. Housewife
e. Seeking for a job
f. Unemployed

8. GDP per month
a. Less than minimum wage
b. Minimum wage - IDR 5 million
c. More than IDR 5 million
72.34
34
58.62
$\begin{array}{lll}17.02 & 14 & 24.14\end{array}$
$\begin{array}{lll}6.38 & 6 & 10.34\end{array}$
d. No income
4.25
5.17

0

I I

18.97

$\begin{array}{ccc}4.25 & 11 & 18.97 \\ 6.38 & 2 & 3.45 \\ 0 & 4 & 6.90 \\ 85.11 & 37 & 63.79 \\ 0 & 1 & 1.72 \\ 4.25 & 3 & 5.17\end{array}$

Most respondents were diagnosed before 2014 making them a long term survivor. This fact indicated that the survival rate of both cancers is particularly long. Surgery was the most utilized therapy for BCS, while the combination of surgery and chemo-radiotherapy was utilized by most CCS. Cervical cancer seemed to be managed more complicatedly compared to breast cancer. Table 2 below shows the primary data of study respondents in details.

Table 2: Primary Data

\begin{tabular}{|c|c|c|c|c|}
\hline \multirow{2}{*}{ Characteristic } & \multicolumn{2}{|c|}{ Cervical Cancer $(\mathrm{N}=47)$} & \multicolumn{2}{|c|}{ Breast Cancer $(\mathrm{N}=58)$} \\
\hline & Frequency & $\%$ & Frequency & $\%$ \\
\hline I. Firstly diagnosed & & & & \\
\hline a. 2018 & 0 & 0 & 4 & 6.90 \\
\hline b. 2017 & 7 & 14.89 & 16 & 27.59 \\
\hline c. 2016 & 12 & 25.53 & 7 & 12.07 \\
\hline d. 2015 & 5 & 8.62 & 10 & 17.24 \\
\hline e. 2014 & 5 & 8.62 & 3 & 5.17 \\
\hline f. $<2014$ & 18 & 38.30 & 18 & 31.03 \\
\hline 2. Type of therapy & & & & \\
\hline a. Surgery & 5 & 8.62 & 26 & 44.83 \\
\hline b. Chemotherapy & 13 & 27.66 & 8 & 13.79 \\
\hline c. Surgery + chemotherapy & 2 & 4.25 & II & 18.97 \\
\hline d. Surgery + radiotherapy & 0 & 0 & I & 1.72 \\
\hline e. Chemotherapy + radiotherapy & 7 & 14.89 & I & 1.72 \\
\hline f. Surgery + chemotherapy + radiotherapy & 17 & 36.17 & 5 & 8.62 \\
\hline $\begin{array}{l}\text { g. Surgery }+ \text { chemotherapy }+ \text { radiotherapy }+ \\
\text { analgesic }\end{array}$ & 1 & 2.13 & 0 & 0 \\
\hline
\end{tabular}




\begin{tabular}{|c|c|c|c|c|}
\hline $\begin{array}{l}\text { h. Surgery }+ \text { chemotherapy }+ \text { radiotherapy }+ \\
\text { medicine }\end{array}$ & I & 2.13 & 0 & 0 \\
\hline i. Surgery + chemotherapy + oral medicine & 0 & 0 & I & 1.72 \\
\hline j. Oral medicine (various types) & 0 & 0 & 4 & 6.90 \\
\hline k. Untreated & 1 & 2.13 & I & 1.72 \\
\hline
\end{tabular}

Most respondents were short term survivors $(42.86 \%$ in total) with sufficient PWB $(70.48 \%$ in total). More acute to short term survivors were found in the case of breast cancer compared to more short to long term survivors in the case of cervical cancer. Sufficient PWB was found in the majority of all stages of survivorship in both cases, but more "high PWB" was found in acute and long term survivors of breast cancer. CCS seemed to be more difficult in achieving high PWB than BCS. Table 3 below shows the PWB level in all stages of cancer survivorship for both cases in details.

Table 3: Comparison of PWB in all stages of survivorship between CCS and BCS

\begin{tabular}{|c|c|c|c|c|}
\hline Case & Survivorship Stage & PWB Level* & Frequency & $\%$ \\
\hline \multirow{9}{*}{$\begin{array}{l}\text { Cervical cancer } \\
\qquad(n=47)\end{array}$} & Acute & Low & 0 & 0 \\
\hline & \multirow[t]{2}{*}{$(n=7)$} & Sufficient & 4 & 57.14 \\
\hline & & High & 3 & 42.86 \\
\hline & \multirow{3}{*}{$\begin{array}{l}\text { Short term } \\
(n=23)\end{array}$} & Low & 0 & 0 \\
\hline & & Sufficient & 19 & 82.61 \\
\hline & & High & 4 & 17.39 \\
\hline & \multirow{3}{*}{$\begin{array}{l}\text { Long term } \\
(n=17)\end{array}$} & Low & 0 & 0 \\
\hline & & Sufficient & 16 & 94.12 \\
\hline & & High & $\mathrm{I}$ & 5.88 \\
\hline \multirow{9}{*}{$\begin{array}{l}\text { Breast cancer } \\
\quad(n=58)\end{array}$} & \multirow{3}{*}{$\begin{array}{l}\text { Acute } \\
(n=20)\end{array}$} & Low & 0 & 0 \\
\hline & & Sufficient & $\mathrm{II}$ & 55.00 \\
\hline & & High & 9 & 45.00 \\
\hline & \multirow{3}{*}{$\begin{array}{l}\text { Short term } \\
(n=22)\end{array}$} & Low & 0 & 0 \\
\hline & & Sufficient & 16 & 72.73 \\
\hline & & High & 6 & 27.27 \\
\hline & \multirow{3}{*}{$\begin{array}{l}\text { Long term } \\
(n=16)\end{array}$} & Low & 0 & 0 \\
\hline & & Sufficient & 8 & 50.00 \\
\hline & & High & 8 & 50.00 \\
\hline
\end{tabular}

* Category was made to ease the data presentation, and not for statistical analysis purposes.

Descriptive statistic results showed that PWB Mean and standard deviation (SD) in the case of cervical cancer was $6 \mathrm{I} .8 \mathrm{I}$ and 6.94 respectively, while for breast cancer was 64.67 and 8.59 respectively. This indicates that averagely sufficient PWB was found in both cases, but the PWB 
data in CCS was more homogenous compared to BCS because of lower SD. One sample Kolmogorov-Smirnov test result showed that all data of PWB were normally distributed $(P=0.457)$, therefore independent sample $T$ test and one way ANOVA test could be used for analyzing the data $(\alpha<0.05)$.

Results of independent sample $T$ test showed that overall PWB between CCS and BCS was not significantly different $(p=0.067)$, but when we looked closely into each item of QOL-CS then we found that only item 9 about appearances which was not significantly different between CCS and BCS $(p=0.706)$. This result indicates that despite differences in signs, symptoms, and treatments existed between cases, appearances of CCS and BCS were not significantly different. Table 4 below explains the comparison of significant PWB differences between CCS and BCS based on QOL-CS. Higher score was found more in BCS for the crucial items marking the significant differences of PWB between CCS and BCS.

Table 4: Comparison of PWB between CCS and BCS

\begin{tabular}{|c|c|c|c|c|c|}
\hline \multirow{2}{*}{ Characteristic* } & \multicolumn{2}{|c|}{ Cervical Cancer $(\mathrm{N}=47)$} & \multicolumn{2}{|c|}{ Breast Cancer $(\mathrm{N}=58)$} & \multirow[t]{2}{*}{ P Value } \\
\hline & Frequency & $\%$ & Frequency & $\%$ & \\
\hline $\begin{array}{l}\text { Item I: life acceptance related to } \\
\text { disease impact }\end{array}$ & & & & & 0.000 \\
\hline a. Low & 10 & 21.28 & 7 & 12.07 & \\
\hline b. Sufficient & 22 & 46.81 & 20 & 34.48 & \\
\hline c. High & 15 & 31.91 & 31 & 53.45 & \\
\hline $\begin{array}{l}\text { Item 2: life acceptance related to } \\
\text { treatment impact }\end{array}$ & & & & & 0.000 \\
\hline a. Low & 17 & 36.17 & 9 & 15.52 & \\
\hline b. Sufficient & 18 & 38.30 & 14 & 24.14 & \\
\hline c. High & 12 & 25.53 & 35 & 60.34 & \\
\hline Item 3: life quality & & & & & 0.002 \\
\hline a. Low & 2 & 4.26 & 2 & 3.45 & \\
\hline b. Sufficient & 38 & 80.85 & 11 & 18.97 & \\
\hline c. High & 7 & 14.89 & 45 & 77.59 & \\
\hline Item 4: happiness & & & & & 0.001 \\
\hline a. Low & 1 & 2.13 & I & 1.72 & \\
\hline b. Sufficient & 18 & 38.30 & 5 & 8.62 & \\
\hline c. High & 28 & 59.57 & 52 & 89.66 & \\
\hline Item 5: take control of life & & & & & 0.000 \\
\hline a. Low & 0 & 0 & I & 1.72 & \\
\hline b. Sufficient & 14 & 29.79 & 7 & 12.07 & \\
\hline c. High & 33 & 70.21 & 50 & 86.21 & \\
\hline Item 6: life satisfaction & & & & & 0.000 \\
\hline a. Low & 0 & 0 & 0 & 0 & \\
\hline b. Sufficient & 19 & 40.43 & 6 & 10.34 & \\
\hline
\end{tabular}




\begin{tabular}{lccccc}
\hline & & & & & \\
\hline c. High & 28 & 59.57 & 52 & 89.66 & 0.003 \\
Item 7: memory/concentration & 2 & 4.26 & 3 & 5.17 & \\
a. Low & 27 & 57.45 & 19 & 32.76 & \\
b. Sufficient & 18 & 38.30 & 36 & 62.07 & 0.000 \\
c. High & & & & & \\
Item 8: usefulness & 1 & 2.13 & 0 & 0 & \\
a. Low & 30 & 63.83 & 14 & 24.14 & \\
b. Sufficient & 16 & 34.04 & 44 & 75.86 & \\
c. High & & & & & \\
Item I0: self concept & 4 & 8.51 & 15 & 25.86 & \\
a. Low & 31 & 65.96 & 7 & 12.07 & \\
b. Sufficient & 12 & 25.53 & 36 & 62.07 & \\
c. High & &
\end{tabular}

* Category was made to ease the data presentation, and not for statistical analysis purposes.

One way ANOVA test result showed that PWB between stages of survivorship in CCS and BCS were also not significantly different $(p=0.425$ and $p=0.135$ respectively). In CCS, item 9 and 10 about appearances and self concept were significantly different between stages of survivorship $(p=0.032$ and $p=0.007$ respectively); while in BCS, item I, 4, 7, and 8 about life acceptance, happiness, memory/concentration, and usefulness were significantly different between stages of survivorship $(p=0.044, p=0.019, p=0.020$, and $p=0.018$ respectively). These results indicate that CCS appearances and self-concept were significantly changing over time along with the duration of survivorship. Meanwhile in BCS, their life acceptance, happiness, memory/concentration, and usefulness were significantly changing over time along with the duration of survivorship.

Table 5 below explains the comparison of significant PWB differences between stages of survivorship in CCS and BCS based on QOL-CS. The majority of CCS had sufficient appearances and self concept in all stages of survivorship, except for more "low self-concept" found in the acute survivors. On the other hand, the majority of BCS had high life acceptance, happiness, and usefulness in all stages of survivorship, except for more sufficient life acceptance and memory/concentration in the short term survivors. 
Table 5: Comparison of PWB between stages of survivorship in CCS and BCS

\begin{tabular}{|c|c|c|c|c|c|c|c|c|}
\hline \multirow[t]{2}{*}{ Case } & \multirow[t]{2}{*}{ Characteristic* } & \multicolumn{2}{|c|}{$\begin{array}{c}\text { Acute } \\
\text { Survivors }\end{array}$} & \multicolumn{2}{|c|}{$\begin{array}{c}\text { Short-Term } \\
\text { Survivors }\end{array}$} & \multicolumn{2}{|c|}{$\begin{array}{c}\text { Long-Term } \\
\text { Survivors }\end{array}$} & \multirow[t]{2}{*}{$\mathrm{P}$ Value } \\
\hline & & $\mathrm{F}$ & $\%$ & $\mathrm{~F}$ & $\%$ & $\mathrm{~F}$ & $\%$ & \\
\hline \multirow{8}{*}{$\begin{array}{c}\text { Cervical } \\
\text { Cancer } \\
(n=47)\end{array}$} & Item 9: appearances & & & & & & & 0.032 \\
\hline & a. Low & 0 & 0 & I & 4.35 & 6 & 35.29 & \\
\hline & b. Sufficient & 5 & 71.43 & 16 & 69.57 & 8 & 47.06 & \\
\hline & c. High & 2 & 28.57 & 6 & 26.09 & 3 & 17.65 & \\
\hline & Item I0: self-concept & & & & & & & 0.007 \\
\hline & a. Low & 4 & 57.14 & 7 & 30.43 & 2 & 11.76 & \\
\hline & b. Sufficient & 3 & 42.86 & 13 & 56.52 & 8 & 47.06 & \\
\hline & c. High & 0 & 0 & 3 & 13.04 & 7 & 41.18 & \\
\hline \multirow{16}{*}{$\begin{array}{l}\text { Breast } \\
\text { Cancer } \\
(n=58)\end{array}$} & $\begin{array}{l}\text { Item I: life acceptance related } \\
\text { to disease impact }\end{array}$ & & & & & & & 0.044 \\
\hline & a. Low & 3 & 15 & 3 & 13.64 & I & 6.25 & \\
\hline & b. Sufficient & 5 & 25.0 & 13 & 59.09 & 6 & 37.50 & \\
\hline & c. High & 12 & 60.0 & 6 & 27.27 & 9 & 56.25 & \\
\hline & Item 4: happiness & & & & & & & 0.019 \\
\hline & a. Low & 0 & 0 & I & 4.55 & 0 & 0 & \\
\hline & b. Sufficient & 2 & 10.0 & 3 & 13.64 & 0 & 0 & \\
\hline & c. High & 18 & 90.0 & 18 & 81.82 & 16 & 100 & \\
\hline & $\begin{array}{l}\text { Item 7: memory/concentration } \\
\text { a. Low }\end{array}$ & & & & & & & 0.020 \\
\hline & b. Sufficient & I & 5.0 & I & 4.55 & I & 6.25 & \\
\hline & c. High & 2 & 10. & II & 50.0 & 6 & 37.5 & \\
\hline & & 17 & 85 & 10 & 45.45 & 9 & 56.25 & \\
\hline & Item 8:usefulness & & & & & & & 0.018 \\
\hline & a. Low & 0 & 0 & 0 & 0 & 0 & 0 & \\
\hline & b. Sufficient & 3 & 15 & 9 & 40.91 & 2 & 12.5 & \\
\hline & c. High & 17 & 85 & 13 & 59.09 & 14 & 87.5 & \\
\hline
\end{tabular}

* Category was made to ease the data presentation, and not for statistical analysis purposes.

It is known that PWB in cancer survivors is the summary of life satisfaction, life quality, happiness, take control of life, life satisfaction, memory/concentration, usefulness, appearances, and self concept (Ferrel, Hassey-Dow, \& Grant, 1995). We tried to determine which one of all these aspects being the best predictor or major determinant of PWB in CCS and BCS. Simple linear regression test results showed that appearances were the best predictor of PWB in both cases, but it gave higher influence in BCS than CCS. Table $6(a$ and $b)$ below explains the influence of each determinant towards PWB in details. 
Table 6a: Predictors of PWB in CCS

\begin{tabular}{clccc}
\hline No. & \multicolumn{1}{c}{ Determinant } & R Square & \% of Influence & P Value \\
\hline I & Life acceptance related to disease impact & 0.007 & - & 0.577 \\
2 & Life acceptance related to treatment & 0.035 & - & 0.21 I \\
& impact & & & \\
3 & Life quality & 0.275 & 27.5 & 0.000 \\
4 & Happiness & 0.237 & 23.7 & 0.001 \\
5 & Take control of life & 0.155 & 15.5 & 0.006 \\
6 & Life satisfaction & 0.249 & 24.9 & 0.000 \\
7 & Memory/concentration & 0.250 & 25 & 0.000 \\
8 & Usefulness & 0.258 & 25.8 & 0.000 \\
9 & Appearances & 0.297 & 29.7 & 0.000 \\
10 & Self concept & 0.201 & 20.1 & 0.002 \\
\hline
\end{tabular}

Table 6a showed that life acceptance (related to disease and treatment impacts) could not significantly predict PWB in CCS. The best predictor of PWB in CCS was appearances with $29.7 \%$ influences, followed by life quality, usefulness, memory/concentration, life satisfaction, happiness, and self concept (all with more than $20 \%$ influences towards PWB). Take control of life was the least significant predictor of PWB with only $15.5 \%$ influences.

Table 6b: Predictors of PWB in BCS

\begin{tabular}{clccc}
\hline No. & \multicolumn{1}{c}{ DETERMINANT } & R SQUARE & \% OF INFLUENCE & P VALUE \\
\hline I & Life acceptance related to disease impact & 0.020 & - & 0.290 \\
2 & Life acceptance related to treatment & 0.022 & - & 0.263 \\
& $\begin{array}{l}\text { impact } \\
3\end{array}$ Life quality & 0.072 & 7.2 & 0.041 \\
4 & Happiness & 0.131 & 13.1 & 0.005 \\
5 & Take control of life & 0.147 & 14.7 & 0.003 \\
6 & Life satisfaction & 0.088 & 8.8 & 0.024 \\
7 & Memory/concentration & 0.290 & 29.0 & 0.000 \\
8 & Usefulness & 0.372 & 37.2 & 0.000 \\
9 & Appearances & 0.526 & 52.6 & 0.000 \\
10 & Self concept & 0.317 & 31.7 & 0.000 \\
\hline
\end{tabular}

Table $6 \mathrm{~b}$ showed that life acceptance (related to disease and treatment impacts) could not significantly predict PWB in BCS. The best predictor of PWB in BCS was appearances with $52.6 \%$ influences, followed by usefulness, self-concept, and memory/concentration (all with more than 20\% influences towards PWB). Life quality was the least significant predictor of PWB with only $7.2 \%$ influences. 


\section{Discussion}

Psychologically, cancer is considered as a traumatic event for most individuals, which trigger many negative emotions, such as anger, hostility, depression, anxiety, and sleep problems (Harrington, Hansen, Moskowitz, Todd, \& Feuerstein, 2010).Fortunately, along with these negative emotions, positive psychological changes could also happen, especially in those who experienced posttraumatic growth (Calhoun \& Tedeschi, 1989), and found benefits in such difficult life situation (Helgeson, Reynolds, \& Tomich, 2006). These positive psychological changes reflected in life acceptance, optimum life quality and satisfaction, happiness, feeling of under control, good memory/concentration, usefulness, good appearance, and high self-concept (Ferrel, Hassey-Dow, \& Grant, 1995). In the case of cancer, the summary of all emotions above, positive and negative, determines the individual's psychological wellbeing (PWB).

Results showed that in CCS and BCS, most respondents were short term survivors $(42.86 \%)$ who had sufficient PWB (70.48\%), in which this PWB was not significantly different between cases and between stages of survivorship ( $p=0.067$ overall, $p=0.425$ in CCS, and $p=0.135$ in $B C S$ ). This indicates that in women living with breast or cervical cancer, their PWB was not significantly changing since first time of diagnosis until the time of their survivorship. The sufficient PWB found in most respondents in both cases at least meant that CCS and BCS still felt a certain portion of gratitude representing their positive emotion after cancer experienced. The role of gratitude has been studied towards 67 BCS (the survivorship stages were not specified), and results showed that gratitude was significantly and positively correlated with PWB, and negatively related to anxiety, depression, and hostility-irritability (Ruini \& Vescovelli, 2013). Similar study in CCS was not found yet.

Other than gratitude, PWB is also associated with demographic characteristic. Two studies towards short term BCS confirmed this statement. A study towards I,684 BCS after 2 years of their breast cancer diagnosis showed that PWB was positively associated with age, family/social support, and inversely associated with educational background, in which a higher level of education may be associated with lower PWB (Bell, et al., 2009). Another study towards 206 BCS within I-5 years after breast cancer diagnosis showed that acculturation, income, cancer stage, and number of co- 
morbidities were statistically significant predictors of PWB; they contributed $42 \%$ of influence towards PWB (Yamada, 2010). Similar study in CCS was not found yet.

In this study, most respondents were middle-aged women (38-62 years old) [69.52\%], Javanese (92.38\%), with income less than minimum wage (64.76\%) because most of them were housewives (73.33\%); who live with spouse (69.52\%) and children (49.52\%), assuring sufficient support from family member. Co-morbidity was not identified. Totally, higher educational background was found in BCS (mostly primary, high school, and university graduated) compared to CCS (mostly primary, secondary, and high school graduated); but the mean of PWB was slightly higher in BCS (64.67) than CCS (6I.8I). By summary from the studies of Ruini \& Vescovelli (20I3), Bell, et al. (2009), and Yamada (2010) in which some PWB predictors were confirmed in this study results, there is a possibility that age, social support, acculturation/ethnic, income, cancer stage, number of comorbidities, and gratitude have more influences towards PWB compared to education level in cancer survivors.

Some sub-variables of PWB were found to change significantly over time along with the period of survivorship. In CCS, appearances and self concept were significantly changing over time $(p=0.032$ and $p=0.007$ respectively).Appearance even was the best predictor of PWB in CCS and BCS $(p=0.000)$, with more influences were found in BCS than CCS $(52.6 \%$ vs. $29.7 \%)$. Appearance is so important because it could speak more than verbal messages; facial expressions, gestures, postures, attire, accessories, and hairstyle for instance. Frequently, most women are aware that they are judged by their appearance more than men, in which young people (20-37 years old), regardless of gender, has the highest awareness of the importance of appearance (Malinowska, DzwonkowskaGodula, Garncarek, Czernecka, \& Brzezinska, 2017). In this study, 100\% study respondents were women, therefore they always aware about their appearances over time; while $20 \%$ respondents were young people, in which more young people were found in BCS (15.24\%); therefore appearance gave more influences towards BCS than CCS.

Other than gender and age, cancer treatment also has significant impact towards appearances. In this study we found most BCS took surgery or mastectomy $(44.83 \%)$ as primary cancer treatment, whether for prophylactic, curative, or palliative purposes. There are 3 types of mastectomy: 
total/modified radical (TMRM), skin-sparing (SSM), and nipple-sparing (NSM). A study towards 79 women at high risk for breast cancer showed that there was a negative trend between appearances orientation with intentions for prophylactic mastectomy (Jhanwar, 2010). This indicates that even before breast cancer diagnosis was established, women were aware and cautious about their appearances after mastectomy. Another study towards 268 BCS who had reconstructive mastectomy showed that there was a trend for the NSM group to be the least satisfied with postoperative appearance, compared to TMRM and SSM (Rojas, et al., 2017). This indicates that although NSM offers BCS the greatest opportunity for preservation of their native skin envelope and potentially enhanced cosmetic outcome, but it is not demonstrate superior sexual function or body image outcomes.

In the other hand, we found more CCS who took a combination of surgery or hysterectomy (partial or total) and chemo-radiotherapy (36.17\%). CCS's appearances are more affected by chemo-radiotherapy than hysterectomy because the impacts are more visible to others, such as weight loss, alopecia, skin damage, and nails changes. Chemotherapy is a therapy that involves the use of chemicals or drugs that aim to kill cancer cells (Rozi, 2013). Appearances was affected by chemotherapy because it cause weight loss due malnutrition induced by severe nausea and vomiting; the most common nutritional problems are poor protein and caloric intake (Trijayanti \& Probosari, 2016; Lara, Morales, Kuba, \& Green, 2013; Sutandyo, 2007). Other than that, alopecia or hair loss usually occur because chemotherapy attacks rapidly dividing cells in the body, including the dividing hair matrix cells (Paus, Haslam, Sharov, \& Botchkarev, 2013). Camp-Sorrel (2018) stated that when some chemotherapy drugs are given intravenously, they can cause the skin and veins to become discolored or darker. Itching or pruritis, the dryness, flaking, or peeling caused by chemotherapy usually goes away once chemotherapy is finished. Morse (2014) stated that changes to fingernails and toenails are common during chemotherapy. These changes include: yellowing, brittleness and cracking, lines across the nail, partial separation of nail from the nail bed, and darkening which happen evenly across the nail if chemotherapy is given continuously.

Skin problems are also common in patients receiving radiotherapy. Dest (2018) stated that during radiation therapy, the skin in the treatment area may look and feel like it is sunburned. How red and irritated the skin gets depends on the dose of radiation and how sensitive your skin cells are to 
the radiation. Radiation therapy can cause the skin to peel, especially in skin folds such as the buttocks, under the breasts and behind the ears. It can also easily peel in areas where the skin is thin, such as on the neck. Skin in the radiation treatment area can become swollen and puffy. Radiation recall, a skin reaction happening after administration of certain chemotherapy drugs (e.g. Doxorubicin) right after radiation therapy, can happen shortly after, a few months after, or a year or more after radiation treatments, in the area of skin where the radiation was given by symptoms of reddish and tender, and skin may peel or blister like sunburns.

Women who loss one or both of her breasts due to mastectomy, lose her womb or cervix only due to hysterectomy, experience various side effects of cancer treatments, may experience an identity crisis and impaired body image impacting roles and social functioning; especially in CCS in which self concept was found to change continuously along with the stages of survivorship $(p=0.007)$. Many factors challenge the self concept of a person undergoing investigations or treatments for cancer. Body image, body ideal, self-esteem, and sense of control are fundamental factors affecting self concept. Altered self concept results from the shifting of a person's internalized standards and stability on which the person bases his/her judgment of the negative and lifethreatening stressor that cancer introduces (Cook, 1999). Cancer symptoms and the side effects of its treatments may cause altered self concept over time in the survivors because they challenge the stability of judgments and shift the person's life standard.

In BCS, more sub-variables of PWB were found to change continuously over time along with the period of survivorship. They were life acceptance, happiness, memory/concentration, and usefulness $(p=0.044, p=0.019, p=0.020$, and $p=0.018$ respectively). Early psychosocial support (counseling) from health professional meets with a high acceptance rate and improves quality of life in BCS. Social support may influence the impact of stressful life events on breast cancer patients' psychological state. A comparative study between women with early $(n=4 I)$ and advanced stage $(n=43)$ breast cancers who received individually tailored psychosocial support for 6 months showed that among the early stage one the disease acceptance was high and the quality of life was improved significantly if compared to those with advanced stage (Scholten, Weinlander, Krainer, Frischenschlager, 200I). Another study towards 286 women at I year after breast cancer diagnosis (short term survivors) showed that firstly at diagnosis BCS reported better emotional, informational, and affectionate support resulted in poorer depressive mood; but after I year, however, perceived social support was significantly decreased and depressive mood was significantly 
improved (Lee, et al., 20II). There is a high possibility that in this study context psychosocial support was not given towards the study respondents as early as possible, or another possibility is that the respondents perceived the received social support from others was decrease over time; therefore their life acceptance also changes over time along with the period of survivorship.

Happiness also changes over time in BCS. The recent phenomenon is interpreting emotional experiences as mental illness, for instance women are encouraged to express their feelings in a certain way until cheerfulness is required and dissent a kind of treason. Confronting mortality and painful feelings is not on the agenda even if empathy for women with breast cancer has become the norm (Vitry, 20I0). In the other hand, usefulness or the feeling to be useful in daily life for others is identically to life functioning in social context. Physical limitation due to cancer and its treatment's side effects often lead BCS to a certain portion of impaired life functioning. Study about usefulness or life functioning in BCS was not found yet. It opens wide chances for researcher to investigate this sub-variable in relation to PWB or quality of life in BCS.

Memory/concentration also changes over time in BCS. Memory is closely related to cognitive function. Cancer treatment is associated with significant cognitive impairments, such as the decline in delayed and immediate verbal episodic memory, which is common among BCS. Generally, breast cancer treatment affects verbal memory, but chemotherapy has a specific negative effect on verbal fluency. A longitudinal study towards I,300 BCS from 18 month to 3 years after diagnosis showed that attention and executive function, immediate and delayed memory significantly improved from I 8 to 36 months after diagnosis in those receiving treatments [Zheng, et al., 20I4]. In this study we found $44.83 \%$ BCS treated by chemotherapy and $10.34 \%$ who were treated by radiotherapy. A comparative study between BCS treated by chemotherapy $(n=4 I)$ and radiotherapy $(n=40)$ showed that receiving any kind of treatment was associated with impaired capacities for recruiting information in verbal memory; verbal fluency was impaired in those receiving chemotherapy specifically (Quesnel, Savard, \& Ivers, 2009).

\section{Conclusion}

Most CCS and BCS in all survivorship stages have sufficient PWB. PWB is not significantly different between cases and stages of survivorship. Various factors may play important roles in determining PWB in cancer survivors, such as age, social support, acculturation/ethnic, income, cancer stage, number of co-morbidities, and the feeling of gratitude. Appearance is the best predictor of PWB in 
CCS and BCS, but it gives more influences towards BCS due to the younger age compared to CCS. Appearances change over time in CCS impacting the changes in self concept, such as body image, self ideal, and self esteem, potentially due to life standard shifting and challenges towards judgment stability. While life acceptance, happiness, memory/concentration, and usefulness change over time in BCS in which various factors may influence these changes, such as psychosocial support, time of first diagnosis, and cognitive declines related to cancer and its treatments.

\section{Acknowledgement}

This study was funded by the Center of Food and Nutritional Research, Institute of Research and Community Service, Widya Mandala Catholic University Surabaya, by Grant number: 077a/WM0I.5.2/N/2018. This publication was supported by Faculty of Nursing, Widya Mandala Catholic University Surabaya.

\section{References}

Abu-Helalah, M. A., Al-Hanaqta, M. M., Alshraideh, H., Abdulbaqi, N., \& Hijazeen, J. (20I4). Quality of life and psychological well-being of breast cancer survivors in Jordan. Asian Pacific Journal of Cancer Prevention, 15 (14), 5927-5936.

Arafah, A. B. R., \& Notobroto, H. B. (2017). Factors associated with housewives behavior in doing breast self-assessment (in Bahasa Indonesia). The Indonesian Journal of Public Health, 12(2), I43153.

Bell, R. J., Lijovic, M., China, M. L., Schwarz, M., Fradkin, P., Bradbury, J., \& Davis, S. R. (20/0). Psychological well-being in a cohort of women with invasive breast cancer nearly 2 years after diagnosis. Support Care Cancer, 18, 921-929.

Bradburn, N. (1969). The Structure of Psychological Well-Being. Chicago: Aldine.

Calhoun, L. G., \& Tedeschi, R. G. (1989). Positive aspects of critical life problems: recollections of grief. Journal of Death \& Dying, 20(4), 265-272.

Camp-Sorrell, D. (2018). Chemotherapy toxicities and management. In Yarbro, C. H., Wujcki D., \&Holmes, G. B. (Eds.), Cancer Nursing: Principles and Practice, $8^{\text {th }}$ Edition (pp. 497-554). Burlington, MA: Jones and Bartlett Learning.

Campo, R. A., Lenjek, K. L., Gaylord-Scott, N., Faurot, K. R., Smith, S., Asher, G., Porterfield, D., \& Gaylord S. A. (2016). Weathering the seasons of cancer survivorship: mind-body therapy use and reported reasons and outcomes by stages of cancer survivorship. Supportive Care in Cancer Survivorship, 24(9),3783-379I. 
Cook, N.F. (1999). Self-concept and cancer: understanding the nursing role. British Journal of Nursing, $8(5), 318$.

Demiray, B., \& Bluck, S. (20|4). Time since birth and time left to live: opposing forces in constructing psychological wellbeing. Ageing and Society, 34(7), I 193-1218.

Dest, V. M. (2018). Radiation therapy: toxicities and management. In Yarbro, C. H., Wujcki, D., \& Holmes, G. B. (Eds.). Cancer Nursing: Principles and Practice, $8^{\text {th }}$ Edition (pp. 333-374). Burlington, MA: Jones and Bartlett Learning.

Diener, E., \& Suh, E. (1997). Measuring quality of life: economic, social, and subjective indicators.Social Indicators Research, 40 (I-2), I89-2I6.

Dodge, R., Daly, A., Huyton, J., \& Sanders, L. (2012). The challenge of defining wellbeing. International Journal of Wellbeing, 2(3), 222-235.

Ferrel, B. R., Hassey-Dow, K., \& Grant, M. (1995). Measurement of The Quality of Life in Cancer Survivors. Quality of Life Research, 4,523-53I.

Forounzafar, M. H., Foreman, K. J., Delossantos, A. M., Lozano, R., Lopez, A. D., Murray, C. J. L., \& Naghavi, M. (20II). Breast and cervical cancer in 187 countries between 1980 and 20I0: a systematic analysis. The Lancet, 378(980I), I46I-I 484.

Harrington, C. B., Hansen, J. A., Moskowitz, M., Todd, B. L., \& Feuerstein, M. (2010). It's not over when it's over: long-term symptoms in cancer survivors-a systematic review. Internal Journal of Psychiatry in Medicine, 40(2), 163-18I.

Helgeson, V. S., Reynolds, K. A., \& Tomich, P. L. (2006). A meta-analytic review of benefit finding and growth. Journal of Consulting and Clinical Psychology, 74(5), 797-8I6.

Jhanwar, S. M. (2010). Influence of body image on intentions for prophylactic mastectomy. Dissertation. New York: Yeshiva University.

Kaplan, M. (2008). The Hispanic outlook in higher education. Paramus, 18( I7), 42-44.

Kubzansky, L. D., Huffman, J. C., Boehm, J. K., Hernandez, R., Kim, E. S., Koga, H. K., Feiq, E. H., Lloyd-Jones, D. M., Selligman, M. E. P., \& Labarthe, D. R. (2018). Positive psychological wellbeing and cardiovascular disease: JACC health promotion series. J Am Coll Cardiol., 72(I2), I382-1396.

La Placa, V., McNaught, A., \& Knight, A. (20/3). Discourse on wellbeing in research and practice. International Journal of Wellbeing, 3(I), II6-125.

Lara, S. K., Morales, U. E., Kuba, M. D., \& Green, D. (2013). Gastrointestinal symptoms and weight loss in cancer patients receiving chemotherapy. Br J Nutr, I09(5), 894-897.

Lee, M. K., Park, S., Lee, E. S., Ro, J., Kang, H. S., Shin, K. H., Lee, K. S., Chung, K. W., Kim, S. W., \& Yun, Y. H. (20l I). Social support and depressive mood I year after diagnosis of breast cancer compared with the general female population: a prospective cohort study. Support Care Cancer, 19, 1379-1392.

Malinowska, E., Dzwonkowska-Godula, K., Garncarek, E., Czernecka, J., \& Brzezińska, J. (2017). Kulturowe Koncepcje Płci I Wieku A Postawy Kobiet I Mężczyzn Wobec Swego Zdrowia I Wygladu [Cultural Concepts of Gender and Age and The Attitudes of Women and Men towards Their Health and Appearance]. Poland: Wydawnictwo Uniwersytetu Łódzkiego [The University of Lodz]. 
Ministry of Health, Republic of Indonesia. (2015). National Cancer Situation in 20/3 [in Bahasa Indonesia].

Retrieved

from

http://www.depkes.go.id/resources/download/pusdatin/infodatin/infodatin-kanker.pdf

Morse, L. (20I4). Skin and nail bed changes. In Yarbro, C. H., Wujcik, D.,\& Holmes, G. B. (Eds.). Cancer Symptom Management, $4^{\text {th }}$ Edition (Pp. 587-616). Burlington, MA: Jones \& Bartlett Learning.

Paus, R., Haslam, I. S., Sharov A. A., \& Botchkarev, V. A. (20/3). Pathobiology of chemotherapyinduced hair loss. Lancet Oncol., 14, e50.

Quesnel, C., Savard, J., \& Ivers, H. (2009). Cognitive impairments associated with breast cancer treatments: results from a longitudinal study. Breast Cancer Res Treat, I 16, I I3-123.

Rika, Y. (2010). Spirituality and psychological well-being among Asian American breast cancer survivors. Dissertation. Los Angeles: Alliant International University.

Rojas, K., Onstad, M., Raker, C., Clark, M. A., Stuckey, A., \& Gass, J. (2017). The impact of mastectomy type on the Female Sexual Function Index (FSFI), satisfaction with appearance, and the reconstructed breast's role in intimacy. Breast Cancer Res Treat, 163, 273-279.

Rozi, M. F. (2013). Easy Tips for Managing Cervical Cancer [in Bahasa Indonesia]. Yogyakarta: Aulia Publisher.

Ruini, C., \& Vescovelli, F. (20I3). The role of gratitude in breast cancer: its relationships with posttraumatic growth, psychological well-being and distress. J Happiness Stud, 14, 263-274.

Sari, N. P. W. P. (20I8). Women living with breast and cervical cancer in the community: the face of Surabaya nowadays.Indonesian Journal of Cancer, 12(4), II6-122.

Scholten, C., Weinlader, G., Krainer, M., Frischenschlager, O., \& Zielinski, C. C. (200I). Difference in patient's acceptance of early versus late initiation of psychosocial support in breast cancer. Supportive Care in Cancer, 9(6), 459-464.

Seraji, M., Shojaeizadeh, D., \& Rakhshani, F. (20I8). Well-being in hemodialysis patients. Iran J Public Health, 47(8), I222-I223.

Sutandyo, N. (2007). Nutrition in cancer patients receiving chemotherapy [in Bahasa Indonesia]. Indonesian Journal of Cancer,4, I44-I48.

Tejawinata S. (2012). Surabaya, the City of Palliative: Its Image and Charm [in Bahasa Indonesia]. Surabaya: Airlangga University Press.

Thomas, J. (2009). Working Paper: Current Measures and the Challenges of Measuring Children's Wellbeing. Newport: Office for National Statistics.

Trijayanti, E., \& Probosari, E. (20/6). Correlation between food intake and nutritional status in cervical cancer patients after chemotherapy [in Bahasa Indonesia]. Jurnal Kedokteran Diponegoro,5(4),75I-760.

Tristiana, D., Kusnanto., Widyawati, I. Y., Yusuf, A., \& Fitryasari, R. (2016). Psychological wellbeing in patients with diabetes mellitus type 2 in Public Health Center of Mulyorejo Surabaya (in Bahasa Indonesia). Jurnal Ners, II (2), I47-I56.

Trudel-Fitzgerald, C., Boehm, J. K., Kivimaki, M., \& Kubzansky, L. D. (20I4). Taking the tension out of hypertension: a prospective study of psychological well being and hypertension. J Hypertens., 32(6), 1222-1228. 
Vitale, S. G., La Rosa, V. L., Rapisarda, A. M. C., \& Lagana, A. S. (2017). Fertility preservation in women with gynaecologic cancer: the impact on quality of life and psychological well-being. Human Fertility, 21 (I), 35-38.

Vitry, A. (20I0). The imperative of happiness for women living with breast cancer. Canadian Woman Studies, 28(2/3): 30-33.

Weathers, E., \& Creedon, R. (20II). The impact of osteoarthritis on psychological wellbeing. $\mathrm{Br} J$ Nurs., 20(4), 243-246.

Yamada, R. (2010). Spirituality and psychological well-being among Asian American breast cancer survivors. Dissertation. Los Angeles: Alliant International University.

Zheng, Y., Luo, J., Bao, P., Cai, H., Hong, Z., Ding, D., Jackson, J. C., Shu, X. O., \& Dai, Q. (20/4). Long-term cognitive function change among breast cancer survivors. Breast Cancer Res Treat, 146,599-609. 